\title{
Variability of mitochondrial DNA D-loop sequences in Zabaikalskaya horse breed
}

\author{
L.A. Khrabrova ${ }^{1} \otimes$, N.V. Blohina ${ }^{1}$, B.Z. Bazaron ${ }^{2}$, T.N. Khamiruev ${ }^{2}$ \\ ${ }^{1}$ All-Russian Research Institute for Horse Breeding, Divovo, Ryazan Region, Russia \\ ${ }^{2}$ Scientific Research Institute of Veterinary Medicine of Eastern Siberia - Branch of the Siberian Federal Scientific Centre of Agro-BioTechnologies \\ of the Russian Academy of Sciences, Chita, Russia \\ ه I.khrabrova@yandex.ru
}

\begin{abstract}
The Zabaikalskaya horse is an indigenous breed of horses from Siberia with diverse use. It is characterized by endurance and good adaptability to year-round herd maintenance in the harsh conditions of the Baikal steppes. To determine the genetic characteristics of the maternal lineage of the Zabaikalskaya horse breed based on mitochondrial DNA polymorphisms, we collected hair samples from 31 horses belonging to breeding farms in the Trans-Baikal Territory. Analysis of the $530 \mathrm{bp}$ sequence of the mtDNA D-loop was performed using the maximum composite likelihood (MCL) model in combination with bootstrap analysis. When studying the polymorphism of the hypervariable region of the mtDNA D-loop in Zabaikalskaya horses, we identified 31 haplotypes representing 8 haplogroups: B, C, G, H, L, M, Q and R according to modern classification. The sequenced fragment of the $D$-loop from nucleotide position 15471 to 16000 contained 17 polymorphic sites, mainly represented by the $A \rightarrow G, G \rightarrow A$ and $T \rightarrow C$ transitions. The haplogroups $Q(25.81 \%), B(19.35 \%), G(16.13 \%)$ and $H(12.90 \%)$ were prevailing in the mtDNA structure of this breed. Genetic analysis of the mitochondrial genome of the Zabaikalskaya horse revealed a high level of diversity of haplotypes and haplogroups, which are typical for the horse populations of Eurasia.
\end{abstract} Key words: genetic diversity; haplogroups mtDNA; horse; phylogenetic analysis; Zabaikalskaya breed.

For citation: Khrabrova L.A., Blohina N.V., Bazaron B.Z., Khamiruev T.N. Variability of mitochondrial DNA D-loop sequences in Zabaikalskaya horse breed. Vavilovskii Zhurnal Genetiki i Selektsii = Vavilov Journal of Genetics and Breeding. 2021;25(5): 486-491. DOI 10.18699/VJ21.055

\section{Вариабельность последовательности D-петли митохондриальной ДНК у лошадей забайкальской породы}

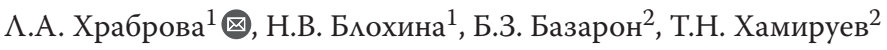 \\ 1 Всероссийский научно-исследовательский институт коневодства, пос. Дивово, Рыбновский район, Рязанская область, Россия \\ ${ }^{2}$ Научно-исследовательский институт ветеринарии Восточной Сибири - филиал Сибирского федерального научного центра агробиотехнологий \\ Российской академии наук, Чита, Россия \\ ه I.khrabrova@yandex.ru
}

\begin{abstract}
Аннотация. Забайкальская лошадь - аборигенная порода лошадей Сибири универсального использования. Она характеризуется выносливостью и хорошей приспособленностью к круглогодичному табунному содержанию в суровых условиях байкальских степей. Для определения генетических особенностей материнских линий забайкальской породы на основе полиморфизмов митохондриальной ДНК мы собрали образцы волос от 31 лошади, принадлежащей племенным хозяйствам Забайкальского края. Анализ последовательности D-петли мтДНК размером 530 п.н. проводили с использованием модели максимального правдоподобия (MCL) в сочетании с бутстрэп-анализом. При изучении полиморфизма гипервариабельного региона D-петли мтДНК у забайкальских лошадей был выявлен 31 гаплотип, представляющий восемь гаплогрупп: B, C, G, H, L, M, Q и R, согласно современной классификации. Секвенированный фрагмент D-петли (нуклеотидная позиция 15471-16000) содержал 17 полиморфных сайтов, в основном представленных транзициями $\mathrm{A} \rightarrow \mathrm{G}, \mathrm{G} \rightarrow \mathrm{A}$ и $\mathrm{T} \rightarrow \mathrm{C}$. В структуре мтДНК породы преобладали гаплогруппы Q (25.81\%), В (19.35 \%), G (16.3\%) и Н (12.90 \%). Генетический анализ митохондриального генома забайкальской лошади выявил высокий уровень разнообразия гаплотипов и гаплогрупп, которые типичны для популяции лошадей Евразии. Ключевые слова: генетическое разнообразие; гаплогруппы мтДНК; лошадь; филогенетический анализ; забайкальская порода.
\end{abstract}

\section{Introduction}

Zabaikalskaya horse is one of the native horse breeds from Siberia and it is distributed in the territories located to the south and southeast of Lake Baikal. The breed was formed through process of long interbreeding of Mongolian horses and later representatives of cultural breeds brought by Russian settlers in the 17th and 18th centuries (Karaush, 1952; Khakimov et al., 2002). As a result, the local population of horses in the Trans-Baikal Territory was significantly improved, resulting in a relatively large array of horses, versatile in their use and well 
adapted to year-round herd maintenance. The Zabaikalskaya horse is characterized by low growth rate but with a massive and bony appearance. In 1993, these horses were given the status of the Zabaikalskaya breed, and it was included in the State Register of Breeding Achievements of the Russian Federation (Khamiruev et al., 2014).

Today, modern genetics technology has allowed researchers to unravel some of the mysteries surrounding the development of Russian native breeds. The study of features of nuclear and mitochondrial DNA of horses of different breeds and areas, including the found remains of ancient horses, allowed clarifying of many important questions of Equids evolution. In particular, high variability of mitochondrial DNA was revealed, indicating the presence of multiple wild ancestors in domestic horses and the existence of different regions of domestication (Bowling, Ruvinski, 2000; Jansen et al., 2002). Due to the study of the mitochondrial genome, it was finally established that the species Equus caballus is not a direct descendant of the wild horse E. ferus przewalski.

The study of the mitochondrial genome of the horse began with the work of X. Xu and U. Arnason (1994), which led to the sequencing of equine mtDNA and demonstrated that its configuration varies due to the different number of GTGCACCT repeats in the control region. Further studies have shown that mtDNA polymorphism can be studied using various technologies, among which the method of direct sequencing of the hyper variable region of the D-loop is most often practiced. This approach allows to study matrilineal diversity within horse breeds and their phylogenetic relationships (Bowling et al., 2000; Hill et al., 2002; Lopes et al., 2006; McGahern et al., 2006; Glazewska et al., 2007; Moridi et al., 2012; Vilstrup et al., 2013).

Comparative analysis of mitochondrial DNA in different populations and breeds of horses in Europe and Asia and phylogenetic reconstruction made on its basis showed the presence of complex variability of mitochondrial haplogroups; this was not observed in other domesticated species (McGahern et al., 2006). Comparison of European and Asian horse breeds revealed differentiated distribution of mtDNA haplogroup variants and evidence of a biogeographic wedge in Asian populations, including association of “Eastern” mtDNA types with haplogroup F. A number of previously unknown additional mtDNA sequences were obtained from horses of Akhal-Teke, Vyatskaya, Mezenskaya, Orlov Trotter and Yakutskaya breeds from Russia, among which the greatest similarity with the European populations was observed in the Mezenskaya horse (McGahern et al., 2006).

A new stage of studying the mitochondrial genome of the horse began in 2012, when a team of researchers led by A. Achilli conducted a complete sequencing of 83 mitochondrial genomes of modern horses in Europe, Asia, the Middle East and America. The phylogenetic analysis with high molecular resolution revealed 18 main haplogroups (A-R) with their diagnostic mutational motifs that arose during the Neolithic period. The researchers concluded that the proposed classification of the encoded and control regions of the mitochondrial genome could be used in the study of the remains of ancient horses, phylogenetic relations of modern breeds, intra-breed diversity and evaluation of the possible connection of mtDNA with racing performance.
Subsequent studies of mitochondrial DNA polymorphism in horses of different populations showed that the number of haplogroups in breeds can vary from 4 to 14 (Bigi et al., 2014; Sorokin, 2015; Cardinali et al., 2016; Khrabrova et al., 2020). The study of mitochondrial sequence variation in 251 Arabian horses from different countries showed that they belong to 13 mtDNA haplogroups based on Achilli (Khanshour, Cothran, 2013). The greatest number of mtDNA haplotypes and haplogroups was revealed in Arab horses of the Syrian population, that is, in the region of creation of this breed. Arabian horses had a much wider range of mitochondrial haplotypes compared to Thoroughbred, with a high frequency of haplogroup L in all populations.

When studying the mitochondrial genome of horses, researchers found a clear association of dam lines with certain mtDNA haplogroups and haplotypes (Hill et al., 2002; Lopes et al., 2006; Sorokin, 2015; Khrabrova et al., 2019). This allows, if necessary, to control the female line of horses using the method of mtDNA sequencing (Bowling et al., 2000; Khrabrova et al., 2020).

The task of our research was to study the variability of the D-loop sequence of mtDNA and maternal lineage in the native Zabaikalskaya horse breed, bred in the steppes of Transbaikalia.

\section{Material and methods}

To analyze the 530 bp hypervariable region of mtDNA D-loop we sequenced 31 Zabaikalskaya horses from Chita State Stable ( $n=13)$ and Kalinin stud $(n=18)$ located in the Trans-Baikal Region. DNA was isolated from hair follicles using a set of ExtraGene DNA Prep 200, produced by laboratory "Isogen" (Moscow), according to the manufacturer's instructions. The original primers for amplification of the studied mtDNA D-loop site were selected by S. Sorokin (2015) taking into account the reference sequence of the fossil Swedish horse X79547 (Xu, Arnason, 1994).

For PCR amplification we used the composition of the reaction mixture included $0.2 \mathrm{mM}$ dNTP, $0.5 \mu \mathrm{M}$ of each primer, $2.5 \mathrm{mM} \mathrm{MgCl}_{2}, 1 \times$ PCR buffer, 1 unit Taq polymerase (PE Applied Biosystems, USA) and 1 unit AmpliTaq Gold polymerase (PE Applied Biosystems), 50 ng DNA. The procedure involved heating the reaction mixture at $95^{\circ} \mathrm{C}(5 \mathrm{~min})$, followed by 30 cycle's denaturation at $94^{\circ} \mathrm{C}(30 \mathrm{~s})$, annealing at $55^{\circ} \mathrm{C}(30 \mathrm{~s})$ and elongation at $72{ }^{\circ} \mathrm{C}(45 \mathrm{~s})$. Final elongation was carried out at $72^{\circ} \mathrm{C}$ for $2 \mathrm{~min}$. The sequencing of the PCR fragment from agarose gel was performed using the Bigdye Terminator Cycle Sequencing Kit (PE Applied Biosystems) on the ABI 3130xl genetic analyzer (PE Applied Biosystems) using manufacturer's protocol.

All mtDNA sequences were prepared with BioEdit 7.2.1. Additional GenBank data set of 18 known haplogroups (A-R) under the number JN398377-JN398457 was used to identify the obtained nucleotide sequences. The phylogenetic analysis of the mtDNA D-loop, including a 530 bp fragment (position 15471-16000) was performed using the NeighborJoining (NJ) method and program MEGA 7 (www.megasoftware.net). The statistical confidence of each node was estimated by 1000 random bootstrap runs. When constructing a phylogenetic tree, bootstrap values of more than $50 \%$ were taken into account. For comparison of mtDNA haplogroups 
distribution in Zabaikalskaya horse, data from 156 Kabardinian, 64 Mongolian (Khaudov et al., 2018), 74 Thoroughbred (Khrabrova et al., 2019) and 22 Vyatskaya horses (Khrabrova et al., 2020) were used.

\section{Results}

Sequence analysis of the 530 bp region of the mitochondrial D-loop of Zabaikalskaya horses showed the presence of 31 haplotypes corresponding to 8 haplogroups: B, C, G, H, L, M, Q and R according to Achilli's classification (2012). The sequenced fragment of the D-loop from 15471 to $16000 \mathrm{nu}-$ cleotide position contained 17 polymorphic sites, mainly represented by the A-G, G-A and T-C transitions (Table 1).

The average number of substitutions per site was $0.03 \pm$ 0.022 , indicating a relatively high level of nucleotide diversity.

Sequences with haplogroups B, G, M and Q were found in both subpopulations of Zabaikalskaya horses. In addition, mtDNA haplogroups $\mathrm{C}$, L and $\mathrm{R}$ were found in horses of the Chita State Stable, while haplogroup $\mathrm{H}$ was found only in the Kalinin stud. The genetic structure of Zabaikalskaya horse was dominated by haplogroups Q (25.81 \%), B (19.35\%), G (16.3\%) and H (12.90\%), which is clearly demonstrated

Table 1. Variability of nucleotides in a 530 bp fragment of the mtDNA D-loop of Zabaikalskaya horse haplotypes compared with reference sequence X79547

\begin{tabular}{|c|c|c|c|c|c|c|c|c|c|c|c|c|c|c|c|c|c|}
\hline ID & 15494 & 15585 & 15597 & 15602 & 15603 & 15604 & 15615 & 15616 & 15617 & 15649 & 15650 & 15720 & 15956 & 17703 & 17720 & 17771 & 17777 \\
\hline X79547 & $T$ & G & A & C & $\mathrm{T}$ & G & A & A & $\mathrm{T}$ & A & A & G & A & $\mathrm{T}$ & G & C & A \\
\hline $126 Z A B$ & $C$ & $A$ & & $\mathrm{~T}$ & $C$ & & & & & G & & A & & & A & $T$ & \\
\hline $127 Z A B$ & C & A & & $\mathrm{T}$ & C & & & & & G & & A & & & A & $T$ & \\
\hline 128ZAB & C & A & & $\mathrm{T}$ & C & & & & & G & & A & & & A & $\mathrm{T}$ & \\
\hline $129 Z A B$ & $C$ & $A$ & & $\mathrm{~T}$ & $C$ & & & & & G & & A & & & A & $\mathrm{T}$ & \\
\hline 130ZAB & C & & & $\mathrm{T}$ & & & & & C & & & A & G & & A & $\mathrm{T}$ & \\
\hline 131ZAB & C & & & & & & & & & & G & A & & & A & & \\
\hline $132 Z A B$ & C & & & & & & & & & & G & A & & & A & & \\
\hline 133ZAB & C & & & & & & & & & & G & A & & & A & & \\
\hline 134ZAB & C & & & & & & & & & & G & A & & & A & & \\
\hline $135 Z A B$ & C & & & $\mathrm{T}$ & & A & & & & & & A & G & C & A & $\mathrm{T}$ & G \\
\hline 136ZAB & C & A & & $\mathrm{T}$ & & A & & & & & & A & G & C & A & $\mathrm{T}$ & G \\
\hline 137ZAB & C & A & G & $\mathrm{T}$ & & & & & & & G & A & & C & A & & \\
\hline 138ZAB & C & & & $\mathrm{T}$ & & A & & & & & & A & G & C & A & $\mathrm{T}$ & G \\
\hline 139ZAB & C & A & G & $\mathrm{T}$ & & & & & & & G & A & & C & A & & \\
\hline 140ZAB & C & A & G & $\mathrm{T}$ & & & & & & & G & A & & C & A & & \\
\hline $141 \mathrm{ZAB}$ & C & & & & & & & & & & G & A & & & A & & \\
\hline 142ZAB & C & A & & $\mathrm{T}$ & & A & & & & & & A & G & C & A & $\mathrm{T}$ & G \\
\hline $143 Z A B$ & C & A & & $\mathrm{T}$ & & A & & & & & & A & $\mathrm{G}$ & $C$ & A & T & G \\
\hline Chardash & $\mathrm{C}$ & & & $\mathrm{T}$ & & & G & G & & & & A & G & C & A & & \\
\hline Praga & C & & & $\mathrm{T}$ & & & & & C & & & A & G & & A & $\mathrm{T}$ & \\
\hline Zabayka & C & A & & $\mathrm{T}$ & & A & & & & & & A & G & C & A & $\mathrm{T}$ & G \\
\hline Arbalet & C & & & $\mathrm{T}$ & & & $\mathrm{G}$ & G & & & & A & G & C & A & & \\
\hline Chegrash & C & & G & $\mathrm{T}$ & & & & & & & G & A & G & & A & & \\
\hline 149ZAB & C & A & G & $\mathrm{T}$ & & & & & & & G & A & & C & A & & \\
\hline 150ZAB & C & & & $\mathrm{T}$ & & & & & C & & & A & G & & A & $\mathrm{T}$ & \\
\hline 151ZAB & C & & & & & & & & & & G & A & & & A & & \\
\hline $152 Z A B$ & C & & G & $\mathrm{T}$ & & & & & & & G & A & & C & A & & \\
\hline 153ZAB & $\mathrm{C}$ & A & & $\mathrm{T}$ & $C$ & A & & & & G & & A & G & & A & $\mathrm{T}$ & \\
\hline 154ZAB & C & A & & $\mathrm{T}$ & & A & & & & & & A & G & C & A & $\mathrm{T}$ & G \\
\hline $155 Z A B$ & C & & & $\mathrm{T}$ & & A & & & & & & A & G & C & A & $\mathrm{T}$ & G \\
\hline $156 Z A B$ & C & & G & $\mathrm{T}$ & & & & & & & G & A & G & & A & & \\
\hline
\end{tabular}




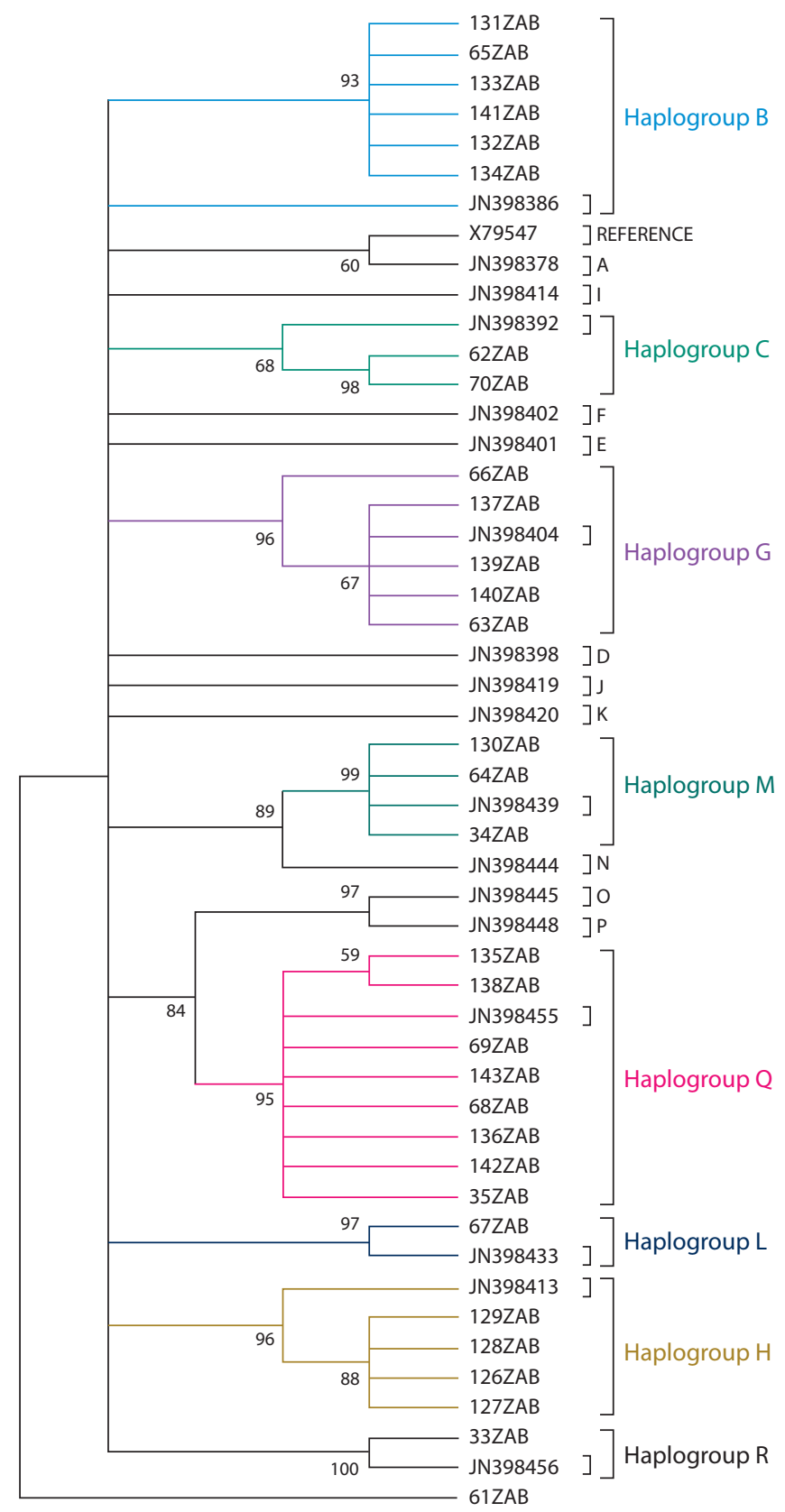

Fig. 1. Phylogenetic tree of mtDNA D-loop sequences from haplotypes of Zabaikalskaya horses constructed by use of the Neighbor-Joining method in combination with bootstrap analysis (bootstrap value $>50$ are shown at nodes).

For identification of haplogroups were used GenBank data (JN398377JN398457) and their classification according to (Achilli et al., 2012).

by the dendrograms in Fig. 1 and 2. Haplotype Q, which combines horses from different farms, is the most common in Asia and the Middle East (Achilli et al., 2012; Khanshour, Cothran, 2013).

The statistical analysis of phylogenetic relationships calculated by the MCL distances shows a fairly high level of bootstrap value (94-100) matching of haplotypes within haplogroups (see Fig. 1). The genetic divergence of the mitochondrial genome of Zabaikalskaya horses from different subpopulations is shown in Figure 2.

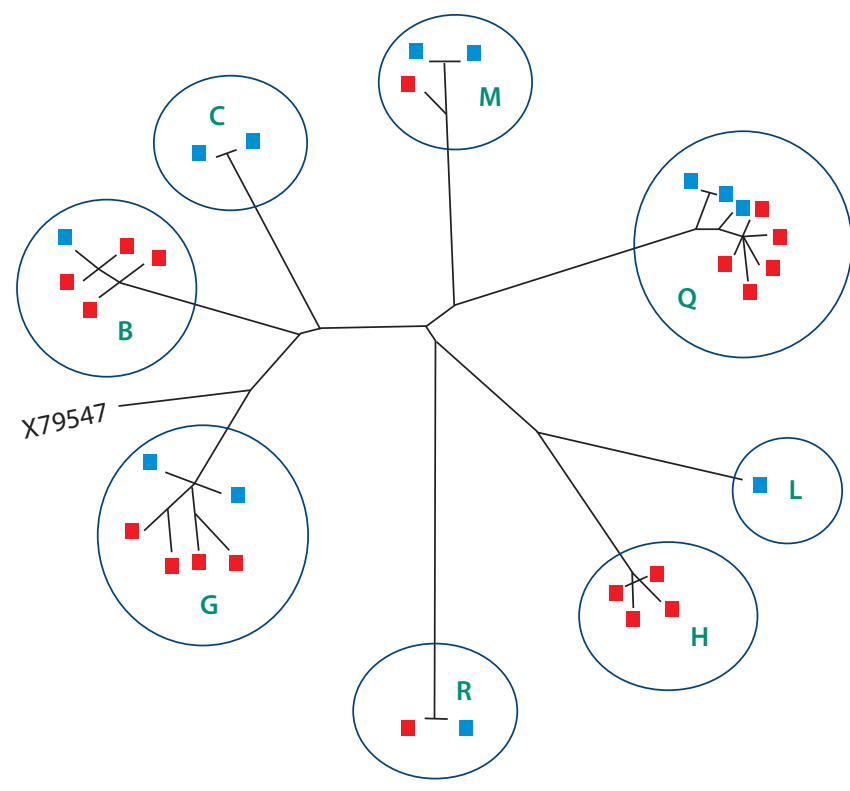

Fig. 2. Scheme of evolutionary relationships between Zabaikalskaya horses from different subpopulations (Chita State Stable - blue, Kalinin stud - red) derived from phylogenetic analysis using Neighbor-Joining method and MEGA7 program.

Most haplotypes of Zabaikalskaya horse (74.19\%) are found in the haplogroups B, G, H and Q; haplogroup L was rarely found, which is typical of many cultural and local breeds (Table 2).

Comparative analysis of mtDNA in horses of different breeds bred in Russia shows that, as a rule, they have a multilinear origin on the maternal line. At the same time, haplogroups B and L were represented quite significantly in all breeds (5.41-36.36 and 3.23-50.0\%, respectively). The genetic analysis of mtDNA of Zabaikalskaya horse breed indicates a high level of diversity of haplotypes and a clear differentiation of I maternal line in the subpopulation of this breed.

\section{Discussion}

The high level of diversity of the genetic structure of mitochondrial DNA and maternal inheritance make it a unique object for the study of evolutionary processes, phylogenetic analysis and evaluation of population diversity (Lukashov, 2009). We found a high mitochondrial polymorphism represented by 31 D-loop haplotypes from 8 haplogroups: B, C, G, H, L, M, Q and R based upon Achilli et al. (2012). In addition, haplogroups A (12.5\%) and D (8.3\%) were identified in the sequences of 24 Zabaikalskaya horse presented in GenBank (Khaudov et al., 2018).

The genetic structure of Zabaikalskaya horse breed shown by mtDNA D-loop haplogroups is generally typical for horse populations in Asia, in which haplogroups B, C, G, and Q were most common (Achilli et al., 2012; Khanshour, Cothran, 2013; Khaudov et al., 2018). It is obvious that the Mongolian horse had a great influence on the formation of Zabaikalskaya horse. The haplogroup variants obtained from the Zabaikalskaya horse were more similar to other local breeds from Siberia (Voronkova, Stolpovskiy, 2018), which indicates their common matrilineal genealogy. 
Table 2. Distribution of the haplogpoups mtDNA (in \%) in different horse breeds

\begin{tabular}{|c|c|c|c|c|c|}
\hline $\begin{array}{l}\text { Haplogroup } \\
\text { mtDNA }\end{array}$ & $\begin{array}{l}\text { Zabaikalskaya } \\
(n=31)\end{array}$ & $\begin{array}{l}\text { Kabardian* } \\
(n=156)\end{array}$ & $\begin{array}{l}\text { Vyatskaya } \\
(n=22)\end{array}$ & $\begin{array}{l}\text { Thoroughbred } \\
(n=74)\end{array}$ & $\begin{array}{l}\text { Mongolian* } \\
(n=64)\end{array}$ \\
\hline A & 0.00 & 6.50 & 4.55 & 4.05 & 6.20 \\
\hline B & 19.35 & 11.00 & 36.36 & 5.41 & 11.00 \\
\hline C & 6.45 & 5.20 & 0.00 & 0.00 & 6.20 \\
\hline$D$ & 0.00 & 2.60 & 0.00 & 0.00 & 3.10 \\
\hline E & 0.00 & 6.50 & 0.00 & 0.00 & 6.20 \\
\hline $\mathrm{F}$ & 0.00 & 0.00 & 0.00 & 0.00 & 0.00 \\
\hline G & 16.13 & 19.50 & 0.00 & 9.46 & 3.10 \\
\hline $\mathrm{H}$ & 12.90 & 0.00 & 0.00 & 2.70 & 1.60 \\
\hline I & 0.00 & 7.20 & 0.00 & 16.21 & 0.00 \\
\hline J & 0.00 & 3.30 & 0.00 & 0.00 & 0.00 \\
\hline K & 0.00 & 0.00 & 0.00 & 0.00 & 0.00 \\
\hline L & 3.23 & 12.30 & 31.82 & 50.00 & 17.20 \\
\hline M & 9.68 & 5.20 & 4.55 & 5.41 & 11.00 \\
\hline $\mathrm{N}$ & 0.00 & 1.90 & 4.55 & 6.76 & 0.00 \\
\hline $\mathrm{O}-\mathrm{P}$ & 0.00 & 5.80 & 4.55 & 0.00 & 12.50 \\
\hline Q & 25.81 & 11.70 & 4.55 & 0.00 & 18.80 \\
\hline $\mathrm{R}$ & 6.45 & 1.30 & 0.00 & 0.00 & 3.10 \\
\hline
\end{tabular}

${ }^{*}$ Date from A.D. Khaudov et al. (2018).

A comparative analysis of polymorphism of microsatellite loci in local horse breeds in Russia showed that Zabaikalskaya horse is characterized by a relatively high level of genetic diversity and has a high level of similarity with Buryat horse (Khrabrova, 2015). Mitochondrial analysis confirms the close relationship of these neighboring breeds, which share 6 common haplogroups: B, G, L, M, Q and R.

Comparison of European and Asian horse breeds revealed differentiated distribution of mtDNA haplogroup variants and evidence of a biogeographic wedge in Asian populations, including association of "Eastern" mtDNA types with haplogroups Q and R. Interestingly, these haplogroups were identified in horses of the Kabardian and Vyatskaya horse breeds bred in the European part of the Russian Federation (Khaudov et al., 2018; Khrabrova et al., 2020), but were absent in the Thoroughbred and Cleveland Bay horses created in England (Khrabrova et al., 2019; Dell et al., 2020).

The study of the sequence of the hypervariable fragment of the mtDNA D-loop makes it possible to assess the interbreed diversity of horses along maternal lines. The data of many researchers confirm the evidence for biogeographic patterning of mtDNA sequences in Eastern horse populations (McGahern et al., 2006; Khanshour, Cothran, 2013; Khaudov et al., 2018).

\section{Conclusion}

The mtDNA analysis of Zabaikalskaya horse identified 31 different haplotypes clustered in 8 haplogroups (B, C, G, H, L, $\mathrm{M}, \mathrm{Q}$ and $\mathrm{R}$ ), which indicates the genetic diversity of the maternal ancestry lines in this breed. Zabaikalskaya horses show high frequencies in haplogroups Q, B, G and H; these haplogroups are also the most common in native horse breeds of Siberia and Mongolian horses. The high variability level of the mitochondrial genome in horses of local breeds may determine good adaptive qualities. The obtained data allow us to supply important information about the genetic features of the existing maternal structure of the Zabaikalskaya horse breed.

\section{References}

Achilli A., Olivieri A., Soares P., Landoni H., Kashani B.H., Perego U.A., Nergadze S.G., Carossa V., Santagostino M., Capomaccio S., Felicetti M., Al-Achkar W., Penedo M.C.T., Verini-Supplizi A., Houshmand M., Woodward S.R., Semino O., Silvestrelli M., Giulotto E., Pereira L., Bandelt H.-J., Torroni A. Mitochondrial genomes from modern horses reveal the major haplogroups that underwent domestication. Proc. Natl. Acad. Sci. USA. 2012;109:7:2449-2454. DOI 10.1073/pnas.1111637109.

Bigi D., Perrota G., Zambonelli P. Genetic analysis of seven Italian horse breeds on mitochondrial DNA D-loop variation. Anim. Genet. 2014;45(4):593-595. DOI 10.1111/age.12156.

Bowling A.T., Del Valle A., Bowling M. A pedigree-based study of mitochondrial D-loop DNA sequence variation among Arabian. Anim. Genet. 2000;31(1):1-7.

Bowling A.T., Ruvinski A. The Genetics of the Horse. Wallingford: CABI Publishing, 2000.

Cardinali I., Lancioni H., Giontella A., Capodiferro M.R., Capomaccio S., Buttazzoni L., Biggio G.P., Cherchi R., Albertini E., Olivieri A., Cappelli K., Achilli A., Silvestrelli M. An overview of ten Italian horse breeds through mitochondrial DNA. PLoS One. 2016; 11(4):e0153004. DOI 10.1371/journal.pone.0153004.

Dell A.C., Curry M.C., Yarnell K.M., Starbuck G.R., Wilson Ph.B. Mitochondrial D-loop sequence variation and maternal lineage in the endangered Cleveland Bay horse. PLoS One. 2020;15(12): e0243247. DOI 10.1371/journal.pone.02443247.

Glazewska I., Wysocka A., Gralak B., Sell J. A new view on dam lines in Polish Arabian horses based on mtDNA analysis. Genet. Sel. Evol. 2007;39(5):609-619. DOI 10.1051/gse:2007025. 
Hill E.W., Bradley M., Al-Barody M., Ertugrul O., Splan R.K., Zakharov I., Cunningham E.P. History and integrity of Thoroughbred dam lines revealed in equine mtDNA variation. Anim. Genet. 2002; 33(4):287-294.

Jansen T., Foster P., Levine M.A., Oelke H., Hurles M., Renfrew C., Weber C., Olek K. Mitochondrial DNA and the origin of the domestic horse. Proc. Natl. Acad. Sci. USA. 2002;99(16):10905-10910. DOI 10.1073/pnas.152330099. PMCID: PMC125071.

Karaush O.N. Zabaikalskaya horse. In: The Book about Horse. Moscow: Selkhozgiz Publ., 1952;1:564-568. (in Russian)

Khakimov N.V., Pankova T.Yu., Vinogradov I.I. To the question of Zabaikalskaya horse. In: Scientific Support for Sustainable Development of the Agro-industrial Complex of East Transbaikalia: Proceedings of the International Scientific-Practical Conference. Chita, 2002;II:102-104. (in Russian)

Khamiruev T.N., Bazaron B.Z., Kalashnikov R.V. Some biological features of the Transbaikal horse. Konevodstvo i Konny Sport $=$ Horse Breeding and Equestrian Sports. 2014;4:20-22. (in Russian)

Khanshour A.M., Cothran E.G. Maternal phylogenetic relationships and genetic variation among Arabian horse populations using whole mitochondrial DNA D-loop sequencing. BMC Genet. 2013;14:83. DOI 10.1186/1471-2156-14-83. PMCID: PMC3847362.

Khaudov A.D., Duduev A.S., Kokov Z.A., Amshokov K.K., Zhekamukhov M.Kh., Zaitsev A.M., Reissmann M. Genetic analysis of maternal and paternal lineages in Kabardian horses by uniparental molecular markers. Open Vet. J. 2018;8(1):40-46. DOI 10.4314/ovj. v8iI.7.

Khrabrova L.A. Characterization of Genetic Horse Breeding Resources in Russia. Lap Lambert Acad. Publ., 2015.

Khrabrova L.A., Zaitsev A.M., Kalashnikov V.V., Blohina N.V., Belousova N.F., Sorokin S.I. Structure of Vyatskaya horse breed by haplogroups mtDNA. Konevodstvo i Konny Sport $=$ Horse Breeding and Equestrian Sports. 2020;4:4-6. DOI 10.25727/HS.2020.4. 62190. (in Russian)

Khrabrova L.A., Zaitsev A.M., Vikulova L.L., Adamkovskaya M.V., Blohina N.V., Sorokin S.I. MtDNA haplotype analysis in dam families of the Thoroughbred riding horses. In: Modern Trends in Agri- cultural Production in the World Economy: Proceedings of XVIII International Scientific and Practical Conference. Kemerovo, Russia, 2019;34-42. DOI 10.32743/kuz.agri.2020.34-42.

Lopes M.S., Mendonca D., Cymbron T., Valera M., da Costa-Ferreira J., da Câmara Machado A. The Lusitano horse maternal lineage based on mitochondrial D-loop sequence variation. Anim. Genet. 2006; 36(3):196-202. DOI 10.1111/j.1365-2052.2005.01279.x.

Lukashov V.V. Molecular Evolution and Phylogenetic Analysis. Moscow: Binom. Laboratoriya Znanij Publ., 2009. (in Russian)

McGahern A., Bower M.A., Edwards C.J., Brophy P.O., Sulimova G., Zakharov I., Vizuete-Forster M., Levine M., Li S., MacHugh D.E., Hil E.W. Evidence for biogeographic patterning of mitochondrial DNA in Eastern horse populations. Anim. Genet. 2006;37(5):494497. DOI 10.1111/j.1365-2052.2006.01495.x.

Moridi M., Masoudi A.A., Vaez Torshizi R., Hill E.W. Mitochondrial DNA D-loop sequence variations in maternal lineages of Iranian native horses. Anim. Genet. 2012;44(2):209-213. DOI 10.1111/ j.1365-2052.2012.02389.x.

Sorokin S.I. Molecular and genetic analysis of D-loop mitochondrial DNA of blood families of Vladimir breed. Konevodstvo i Konny Sport $=$ Horse Breeding and Equestrian Sports. 2015;6:27-29. (in Russian)

Vilstrup J.T., Seguin-Orlando A., Stiller M., Ginolhac A., Raghavan M., Nielsen S.C.A., Weinstock J., Froese D., Vasiliev S.K., Ovodov N.D., Clary J., Helgen K.M., Fleischer R.C., Cooper A., Shapiro B., Orlando L. Mitochondrial phylogenomics of modern and ancient equids. PLoS One. 2013;8(2):e55950. DOI 10.1371/ journal.pone.0055950. PMCID: PMCPMC3577844.

Voronkova V.N., Stolpovskiy Yu.A. Assessment of the genetic diversity of native breeds of the Sayano-Altai region using nuclear and mitochondrial DNA markers. In: Aboriginal Horse Breeding in Russia: History, Present, Prospects: Proceedings of II All-Russian Res. Pract. Conference. Arkhangelsk, 2018;60-69. (in Russian)

Xu X., Arnason U. The complete mitochondrial DNA sequence of the horse. Equus caballus: extensive heteroplasmy of control region. Gene. 1994;1480:357-362.

ORCID ID

L.A. Khrabrova orcid.org/0000-0003-2590-8472

N.V. Blohina orcid.org/0000-0001-7406-6385

B.Z. Bazaron orcid.org/0000-0001-7525-5815

T.N. Khamiruev orcid.org/0000-0002-0147-2929

Acknowledgements. The research was supported by the Russian Science Foundation (project No. 19-7620058).

We thank all Zabaikalskaya horse breeders for their support and Dr. Sergey Sorokin (Laboratory HorseGene, Moscow) for helping with laboratory analysis. Conflict of interest. The authors declare no conflict of interest.

Received January 29, 2021. Revised March 28, 2021. Accepted April 8, 2021. 